\title{
Silurian rugose corals from the Kurosegawa Terrane, Southwest Japan, and their paleobiogeographic implications
}

\author{
ERIKA KIDO \& TETSUO SUGIYAMA
}

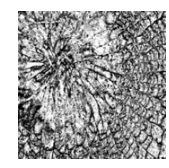

\begin{abstract}
The Silurian to Devonian Gionyama Formation is assigned to the Kurosegawa Terrane in Southwest Japan. Abundant rugose corals in the Middle Member (late Llandovery to early Ludlow) of this formation represent 18 species belonging to 13 genera. These species are: Tryplasma sp. aff. T. ozakii, Tryplasma sp. A, Tryplasma sp. B, Cystiphyllum sp., Holmophyllum sp., Holmophyllum? sp., Labechiellata regularis, Rhizophyllum sp. A, Rhizophyllum sp. B, Neobrachyelasma japonica, Pseudamplexus sp., Amsdenoides sp., Amplexoides sp. aff. A. chaoi, Strombodes sp., Nanshanophyllum hamadai, N. gokasense, Shensiphyllum sp., and Ptychophyllum sp. The rugose corals from the Gionyama Formation include cosmopolitan genera that commonly occur in China, Kazakhstan, Siberia, Gotland, eastern Australia, and North America. Endemic genera, such as Nanshanophyllum and Shensiphyllum, which only occur in South China and Qaidam, are also present. Their stratigraphic ranges are restricted to the late Llandovery. The occurrences of these endemic genera may indicate a strong paleobiogeographic relation between the South China Block and 'Proto-Japan' during the Silurian. - Key words: Gionyama Formation, Kurosegawa Terrane, 'Proto-Japan', paleobiogeography, Silurian rugose corals.
\end{abstract}

Kido, E. \& SugiYama, T. 2011. Silurian rugose corals from the Kurosegawa Terrane, Southwest Japan, and their paleobiogeographic implications. Bulletin of Geosciences 86(1), 49-61 (8 figures). Czech Geological Survey, Prague. ISSN1214-1119. Manuscript received October 5, 2010; accepted in revised form November 29, 2010; published online January 27, 2011; issued March 14, 2011.

Erika Kido (corresponding author), Institute for Earth Sciences (Geology and Palaeontology), University of Graz, Heinrichstrasse 26, A-8010 Graz, Austria; erikakido07@yahoo.co.jp•Tetsuo Sugiyama, Department of Earth System Science, Faculty of Science, Fukuoka University, 8-19-1 Nanakuma, Jonan-ku, Fukuoka 814-0180, Japan; sugiyama@fukuoka-u.ac.jp

The Silurian to Devonian Gionyama Formation is exposed in the Gokase-cho, Miyazaki Prefecture, and is assigned to the Kurosegawa Terrane in Southwest Japan. Silurian corals from this formation were studied by Hamada (1959, 1961), Kato (1990), Adachi \& Niko (1996), Niko (1998), and Niko \& Adachi (1999a, b, 2000, 2002) and 35 species in 27 genera of tabulate corals have been documented. After Hamada $(1959,1961)$ reported, without illustrations, four species in four genera of rugose corals from the Gionyama Formation, the rugose corals had not been studied carefully until Kido \& Sugiyama (2005) documented that abundant and diverse rugose corals, including 17 species in 12 genera, occurred in this formation. The Silurian to Devonian strata in the Kurosegawa Terrane extend into the Yokokurayama, Imose, and Mitakiyama areas in Shikoku Island (Fig. 1A). Silurian and Devonian strata are also known in the Hikoroichi and Arisu areas in the South Kitakami Terrane, and the Fukuji area in the Hida 'Gaien' Belt. The Silurian corals from the Kurosegawa Terrane have been compared with those from the South Kitakami Terrane and the Hida 'Gaien' Belt (Hamada 1961, Kido \& Sugiyama 2005).

The Japanese Islands are composed of several terranes accreted one by one during the past $450 \mathrm{Ma}$ along with a typical subduction zone. 'Proto-Japan' was either a marginal area of the South China Block (Isozaki 1998) or within the North China Block (Tazawa 2004). The Kurosegawa and South Kitakami terranes, and the Hida 'Gaien' Belt contain Paleozoic strata which accumulated before these two continental blocks were amalgamated, some time between the Triassic and the Early Jurassic. Paleobiogeographic information from the different terranes is important for understanding the original location of 'Proto-Japan'. Paleobiogeographic data were known from radiolarians, brachiopods, corals, and trilobites in the Silurian to Devonian strata in the Kurosegawa and South Kitakami terranes, and Hida 
'Gaien' Belt (Hamada 1961, Kobayashi \& Hamada 1988, Kurihara \& Sashida 1998, Umeda 1996). However, information based on the Silurian rugose corals from the Kurosegawa Terrane was obviously insufficient compared with similar data from the South Kitakami Terrane. Recently, Kido (2009a, b, 2010) provided detailed taxonomic study of ten rugosan species belonging to six genera from the Gionyama Formation and described paleobiogeographic relation of these rugose corals.

Here we present the results of a careful study of the rugose corals from the Gionyama Formation, which in total revealed occurrences of 18 species in 13 genera. On the basis of our study, we concluded that 'Proto-Japan' and the South China Block were closely related during the Silurian.

All specimens of rugose corals with the abbreviation "GF. D" reported herein are deposited at Fukuoka University, Kyushu, Japan.

\section{Geology of study area}

The Gionyama Formation (Saito \& Kanbe 1954) is well exposed around Mt. Gionyama, Gokase-cho, Miyazaki Prefecture in southwest Japan (Fig. 1A). Detailed geology of the western part of Mt. Gionyama is shown in Fig. 1B. The northern half of the mountain is composed of Kuraoka Igneous Rocks (Kanbe 1957) that have been dated as $450 \mathrm{Ma}$ by the K-Ar method (Umeda et al. 1986). On the southern slope of Mt. Gionyama the Gionyama Formation is bounded by fault with the Upper Devonian, Naidaijin Formation (Fig. 1B).

Hamada (1959) divided the Gionyama Formation into four lithologic and biostratigraphic units, 'Members' G1 to G4 in ascending order. Radiolarian biostratigraphy (Umeda 1997) and a sedimentological study of the limestone conglomerate indicate that these subdivisions are not suitable. Kido \& Sugiyama (2007) divided this formation, on the basis of lithostratigraphy, into three members: Lower, Middle, and Upper (Figs 1B, 2). The Lower Member is exposed only on the western slope of Mt. Gionyama as shown in Figs 1B and 2. This member is bounded by a fault with the Middle Member of the Gionyama Formation. The relationship of the contact between the Middle and Upper members is not clear in the western part of Mt. Gionyama, but the boundary may be sharp as a transitional facies is not observed.

\section{Lower Member}

The Lower Member (over 100 m thick) is mostly sandstone with intercalations of greenish siliceous tuff. This member is correlative with the G1 Member and the lowest part of G2 Member as designated by Hamada (1959). The true thickness of the Lower Member is unknown because the exposed base of this member is bounded with the Kuraoka Igneous Rocks by faults. Wakamatsu et al. (1990) described the late Llandovery to Wenlock radiolarians from the Lower Member.

\section{Middle Member}

The Middle Member (about $300 \mathrm{~m}$ thick) is a limestone conglomerate intercalated with thin lenticular tuffaceous shales or sandstones. Some of the limestone conglomerates are supported by non-calcareous clastics with greenish to yellowish brown color, which are equivalent to the G2 facies limestones of Hamada (1959). Other limestone conglomerates are massive with stylolitization caused by pressure solution and contain a few non-calcareous matrices or none at all. This non-calcareous matrices show green to yellow, pink to purple, or gray color. These conglomerates are exposed on the slope of Mt. Gionyama as a thick wall and represent the G3 facies limestones described by Hamada (1959). The limestone conglomerate of the Middle Member is very fossiliferous, with corals, crinoids, bryozoans, stromatoporoids, brachiopods, trilobites, bivalves, cephalopods, and gastropods (Hamada 1961, Kido \& Sugiyama 2005). The bed of limestone conglomerates which are massive and contain none or a few non-calcareous matrices does not overlie the bed of limestone conglomerate supported by non-calcareous matrices as interpreted by Hamada (1959). The latter bed is interbedded with the former and in some cases pinches out laterally (Figs 1B, 2A). These lithologic characteristics suggest that the limestone conglomerates of the Middle Member were transported from shallow reefal area as debris flows and deposited on a reef slope or along a reef front where deposition of acidic tuffs was dominant (Kawamura et al. 2003, Kido \& Sugiyama 2007). The geological age of the Middle Member is late Llandovery to early Ludlow based on the corals described in this study.

\section{Upper Member}

The Upper Member (up to a maximum of $450 \mathrm{~m}$ thick) is mainly composed of acidic tuff. This member is equivalent to the G4 Member of Hamada (1959). Umeda (1997) found radiolarian assemblages in this member and reported an age ranging from the late Wenlock to early Middle Devonian. Additionally, he suggested that, based on the age of radiolarian, part of the Upper Member might be a contemporaneous heterotopic facies of the limestone conglomerates of the Middle Member. 


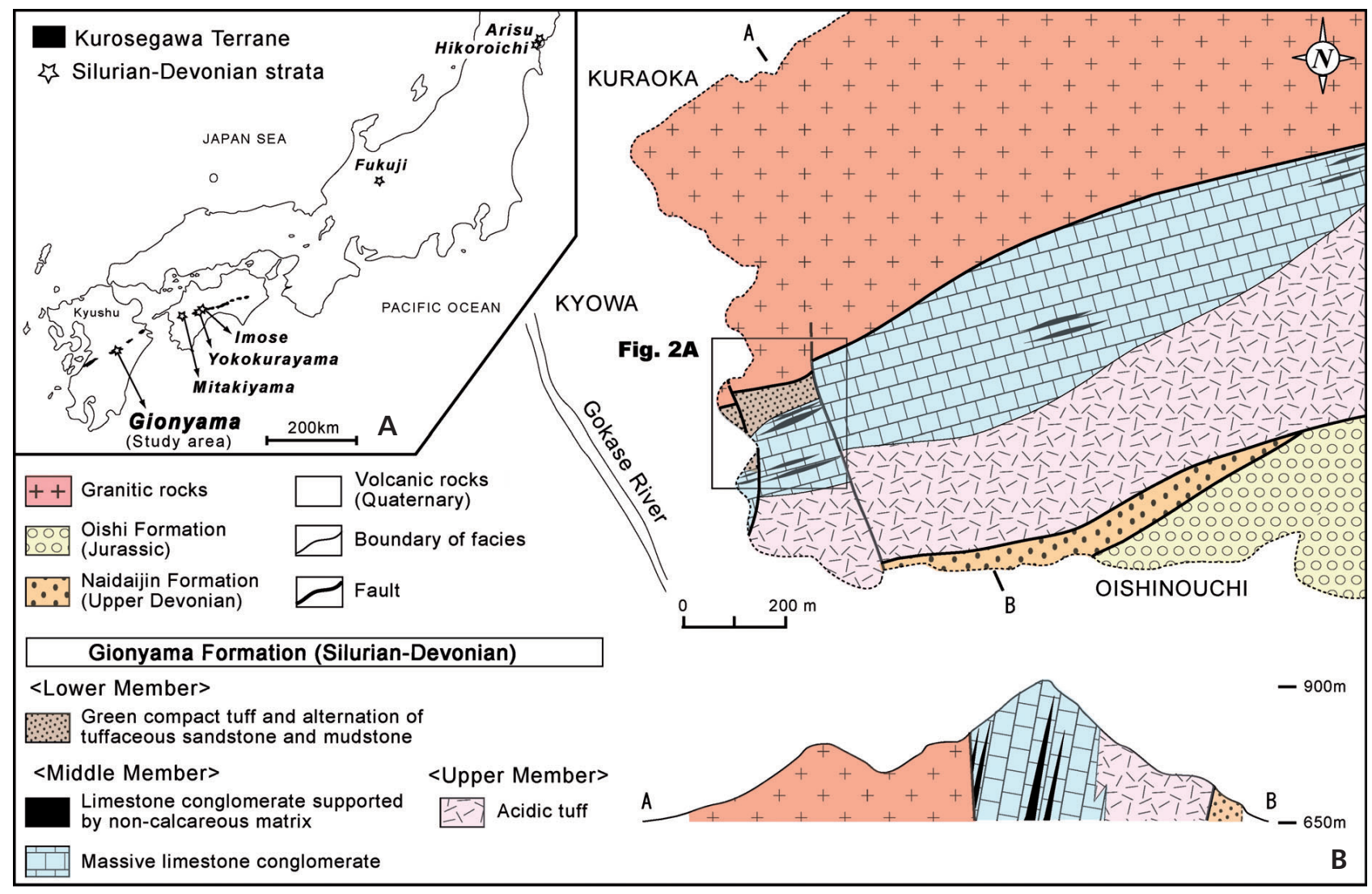

Figure 1. A-index map showing distribution of the Kurosegawa Terrane, study area (Gionyama), and the localities of Silurian to Devonian strata in Japan. $\bullet$ B - geological map with cross section of the western part of Mt. Gionyama. Modified from Kido (2009a).

\section{Coral occurrences and their correlation}

Silurian rugose corals reported in this paper were collected from four localities, KL1 to 4, in the Middle Member exposed on the southwestern slope of Mt. Gionyama (see Fig. 2A). The stratigraphic positions of these localities are provided in Fig. 2B. The rugose coral species of each locality are listed in Fig. 3 (the number of obtained specimens is given in parentheses). Distinctive sections of some corals (Tryplasma sp. aff. T. ozakii, Tryplasma sp. A, Tryplasma sp. B, Cystiphyllum sp., Rhizophyllum sp. A, Rhizophyllum sp. B, Strombodes sp. and Ptychophyllum sp.) are illustrated in Fig. 4. Regarding other rugose corals, the reader is referred to illustrations in Kido (2009a, b, 2010).

Hamada (1959) divided the fossiliferous calcareous part of the Gionyama Formation into the lower G2 Member and the upper G3 Member. He mentioned the different biostratigraphic characteristics of the $\mathrm{G} 2$ and $\mathrm{G} 3$ members; the G2 characterized by Falsicatenipora shikokuensis, Acanthohalysites kuraokensis, and Coronocephalus kobayashii, and the G3 containing Schedohalysites kitakamiensis, Zelophyllum sp., and Conchidium sp. cf. C. knightii. Hamada (1959) correlated the G2 Member with upper Wenlock and the G3 with the lower Ludlow.
However, these two members are limestone conglomerates containing different amount of non-calcareous matrices, and they are interbedded and pinch out laterally. Additionally the corals in these two limestone conglomerates are similar. The tabulate corals Falsicatenipora shikokuensis and Acanthohalysites kuraokensis, as well as Schedohalysites kitakamiensis occur at Loc. KL1. This study treats the fossiliferous limestones as a single stratigraphic unit of the Middle Member.

\section{Correlation based on rugose corals}

Among the rugose corals found during this study, Nanshanophyllum and Shensiphyllum are useful for determining the geological age of the Middle Member (Kido 2009a). Nanshanophyllum is reported from the upper Llandovery and occurs in the Ningqiang Formation of the Guangyuan, Sichuan (He 1978), the Xiushan Formation of the Shimen, Hunan (Ge \& Yü 1974), the Zhugqu Group of the Zhugqu, Gansu (Cao \& Lin 1982), and the Daluzhai Formation of the Daguan, Yunnan (Chen et al. 2005) and from the upper Llandovery to the lower Wenlock of the Quannaogou Formation of the Yumen, Gansu (Yü 1956). Shensiphyllum is 


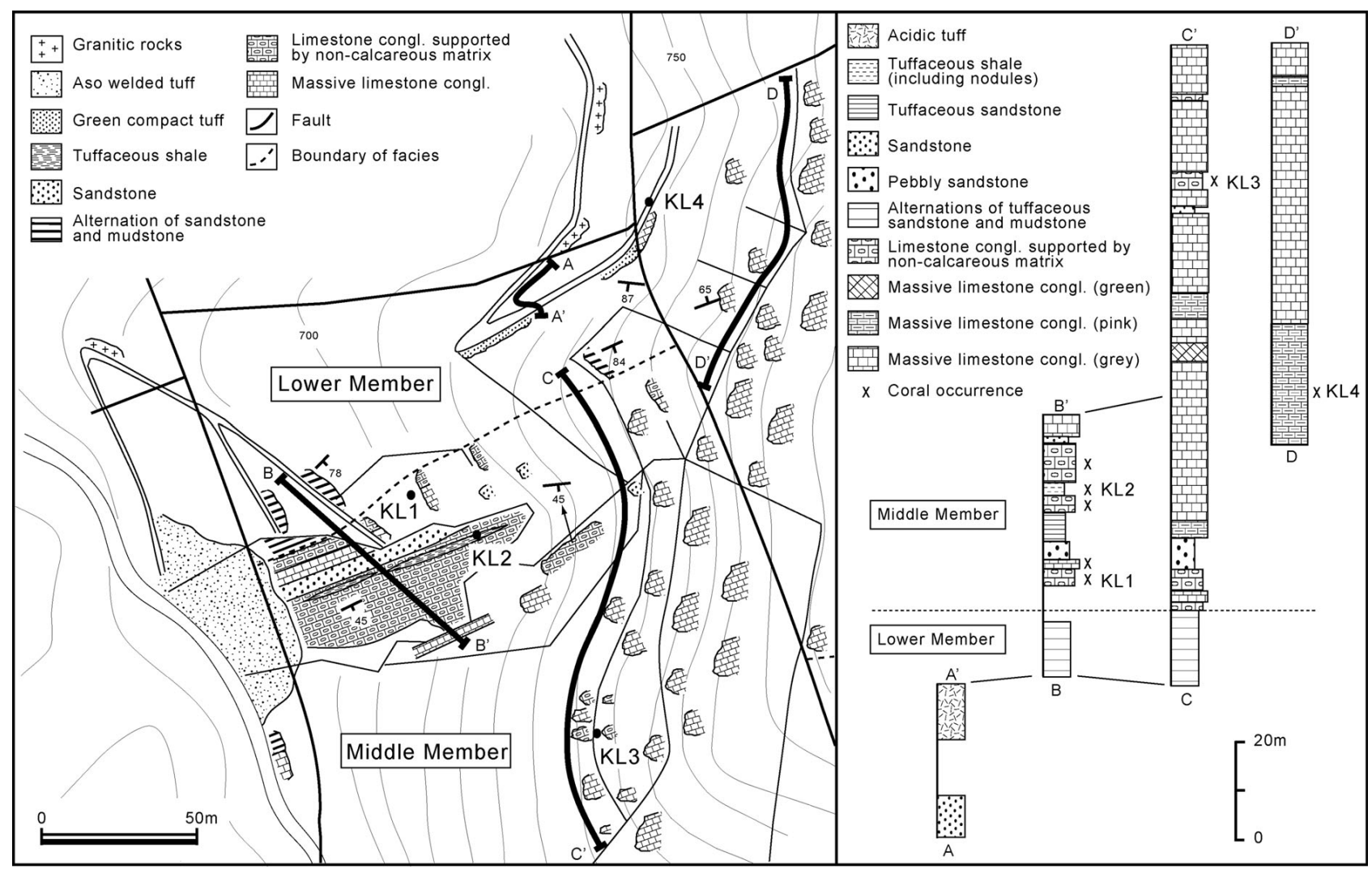

Figure 2. A - collecting sites of corals (KL1 to 4), location of measured columnar sections (A-A' to D-D'), and exposures of the Lower and Middle members of the Gionyama Formation on the western slope of Mt. Gionyama. • B - measured columnar sections, A-A' to D-D', as indicated in Fig. 2A. Sections show the lithologic character and stratigraphic position of coral localities (KL1-4). Slightly modified from Kido (2009a).

\begin{tabular}{|l|l|}
\hline$\vec{y}$ & Tryplasma sp. B (1) \\
\hline$\vec{z}$ & Nanshanophyllum gokasense Kido, 2009a (1) \\
\hline \multirow{2}{*}{} & $\begin{array}{l}\text { Cystiphyllum sp. (1) } \\
\text { Neobrachyelasma japonica Kido, 2010 (43) } \\
\text { Amplexoides sp. aff. A. chaoi (Grabau, 1925) (39) } \\
\text { Nanshanophyllum hamadai Kido, 2009a (18) }\end{array}$ \\
\hline & $\begin{array}{l}\text { Tryplasma sp. aff. T. ozakii Sugiyama, 1940 (24) } \\
\text { Tryplasma sp. A (1) } \\
\text { Tryplasma sp. B (4) } \\
\text { Cystiphyllum sp. (3) } \\
\text { Holmophyllum sp. (4) } \\
\text { Holmophyllum? sp. (2) } \\
\text { Labechiellata regularis (Sugiyama, 1939) (12) } \\
\text { Rhizophyllum sp. A (4) } \\
\text { Rhizophyllum sp. B (6) } \\
\text { Pseudamplexus sp. (1) } \\
\text { Amsdenoides sp. (1) } \\
\text { Strombodes sp. (13) } \\
\text { Nanshanophyllum gokasense Kido, 2009a (14) } \\
\text { Shensiphyllum sp. (1) } \\
\text { Ptychophyllum sp. (1) }\end{array}$ \\
\hline
\end{tabular}

Figure 3. Rugose corals collected from the four localities, KL1 to 4. Number of specimens examined in each species is shown in parentheses. known from the upper Llandovery of South China and occurs in the Ningqiang Formation of the NingqiangGuangyuan area near the border of Shaanxi and Sichuan (Ge \& Yü 1974, He 1978) and the Daluzhai Formation of the Daguan, Northeast Yunnan (Chen et al. 2005). Scrutton \& Deng (2002) and Chen et al. (2005) compiled the occurrences of Nanshanophyllum and Shensiphyllum and re-examined their stratigraphic ranges. Based on their compilation, in China, these two genera occur only in the Monoclimacis griestoniensis-M. crenulata graptolite biozones which are related to the middle to late Telychian in the late Llandovery.

Nanshanophyllum hamadai was also found in the Fukata Formation of the Yokokurayama Group (Umeda 1998) in the Kurosegawa Terrane, which is exposed in the Yokokurayama area of Shikoku Island (Fig. 1A). Hamada (1959) correlated his G2 and G3 members of the Gionyama Formation with the Fukata Formation based on halysitid corals. Kuwano (1976) suggested that the geological age of the Fukata Formation ranged from the late Llandovery to the early middle Ludlow based on conodonts such as Ambalodus galerus, Ozarkodina excavata excavata, Pterospathodus amorphognathoides, and Panderodus sp. Rong \& Chen (2003) regarded A. galerus as a critical element for 

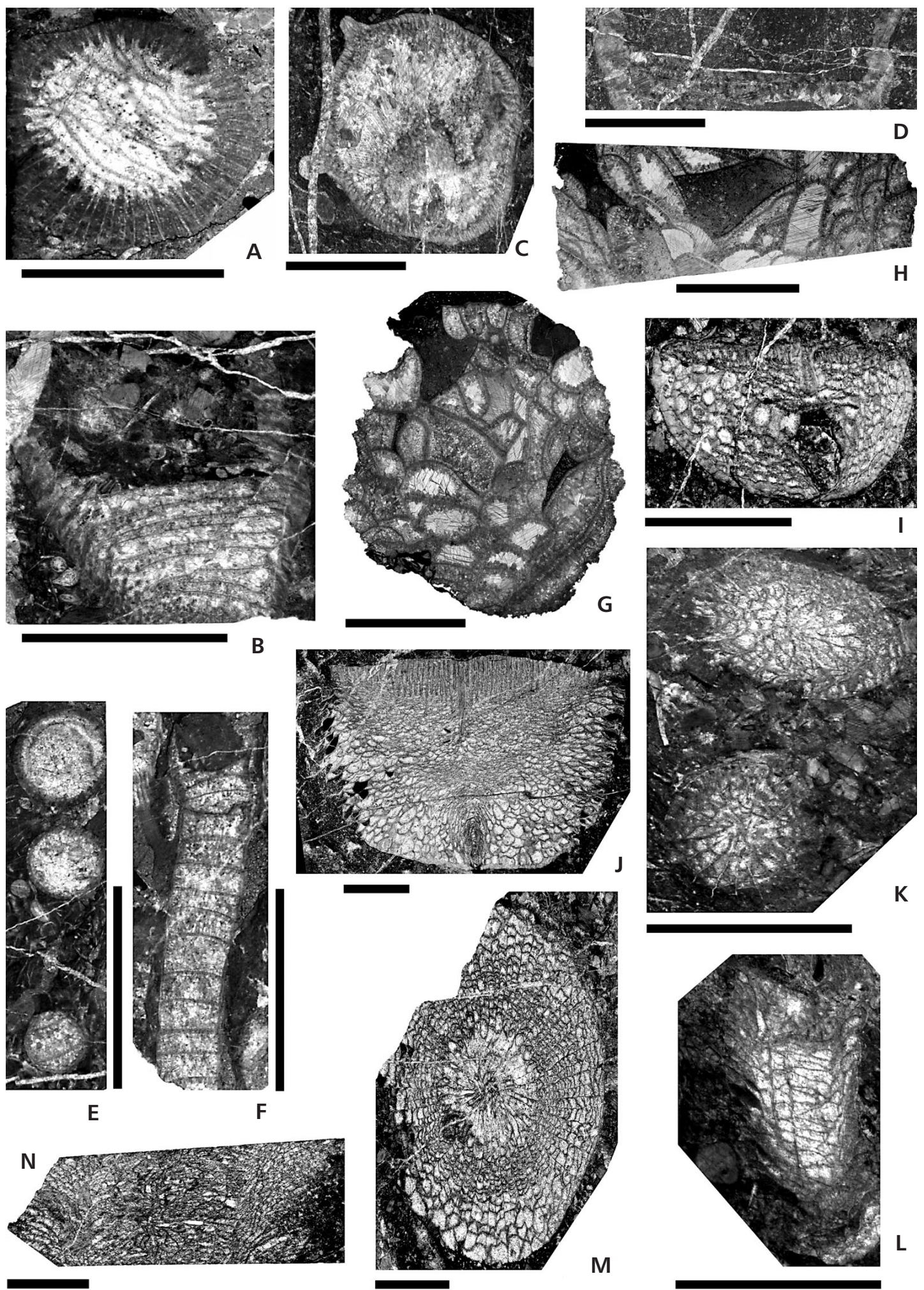

Figure 4. A, B - Tryplasma sp. aff. T. ozakii Sugiyama. • A - transverse section, B - longitudinal section, GF. D 25141a, 25158b, respectively, Loc. KL1. • C, D - Tryplasma sp. A. C - transverse section, D - longitudinal section, GF. D 25142a, c, respectively, Loc. KL1. E, F - Tryplasma sp. B. E - transverse section, F - longitudinal section, GF. D 25143a, Loc. KL4. $\bullet \mathrm{G}, \mathrm{H}-$ Cystiphyllum sp. G - transverse section, H - longitudinal section, GF. D 25145c, d, respectively, Loc. KL 2. I - Rhizophyllum sp. A. Transverse section, GF. D 21005, Loc. KL1. • J Rhizophyllum sp. B. Transverse section, GF. D 25146, Loc. KL1. • K, L - Strombodes sp. K - transverse section, L - longitudinal section, GF. D 25147b, 25149 b, respectively, Loc. KL1. - M, N-Ptychophyllum sp. M - transverse section, N-longitudinal section, GF. D 25148a, b, respectively, Loc. KL1. All scale bars equate to $10 \mathrm{~mm}$. 


\begin{tabular}{|c|c|c|c|c|c|c|c|}
\hline Region & & $\begin{array}{l}\text { Kurose } \\
\text { Terran }\end{array}$ & & & $\begin{array}{l}\text { Hida- } \\
\text { 'Gaien' } \\
\text { Belt }\end{array}$ & $\begin{array}{l}\text { Sout } \\
\text { Kitak } \\
\text { Terra }\end{array}$ & $\begin{array}{l}\text { th } \\
\text { kami } \\
\text { ane }\end{array}$ \\
\hline $\begin{array}{l}\text { Rugose coral } \\
\text { genera from } \\
\text { Japanese Silurian }\end{array}$ & 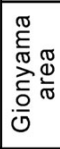 & 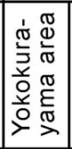 & 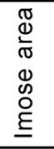 & 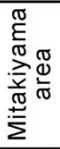 & 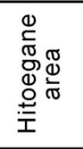 & 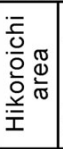 & 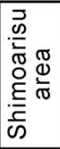 \\
\hline $\begin{array}{l}\text { Cyathophylloides } \\
\text { Pilophyllum } \\
\text { Neocystiphyllum } \\
\text { Spongophyllum } \\
\text { Kitakamiphyllum } \\
\text { Hedstroemophyllum } \\
\text { Nipponophyllum } \\
\text { Zaphrentid }\end{array}$ & & 0 & 0 & 0 & & $\begin{array}{l}0 \\
0 \\
0 \\
0 \\
0 \\
0\end{array}$ & \\
\hline $\begin{array}{l}\text { Tryplasma } \\
\text { Cystiphyllum }\end{array}$ & O- & -0 & & - & & & -0 \\
\hline $\begin{array}{l}\text { Holmophyllum } \\
\text { Labechiellata }\end{array}$ & $\begin{array}{l}0- \\
0\end{array}$ & - & 0 & & & -0 & \\
\hline $\begin{array}{l}\text { Rhizophyllum } \\
\text { Kodonophyllum } \\
\text { Neobrachyelasma }\end{array}$ & $\begin{array}{l}0- \\
0 \\
0\end{array}$ & - & & & -0 & -0 & -0 \\
\hline $\begin{array}{l}\text { Pseudamplexus } \\
\text { Amsdenoides }\end{array}$ & $\begin{array}{l}0 \\
0\end{array}$ & & & & & -0 & $\begin{array}{l}-0 \\
-0\end{array}$ \\
\hline $\begin{array}{l}\text { Pycnostylus } \\
\text { Zelophyllum } \\
\text { Amplexoides } \\
\text { Strombodes } \\
\text { Nanshanophyllum } \\
\text { Shensiphyllum } \\
\text { Ptychophyllum }\end{array}$ & $\begin{array}{l}0 \\
0 \\
0 \\
0 \\
0 \\
0 \\
0\end{array}$ & - & & & & & \\
\hline
\end{tabular}

Figure 5. Silurian rugose corals from Japan, based on Sugiyama (1940), Hamada (1961), Kato et al. (1980) and present study. Circle indicates the presence of each rugosan genus, and a horizontal line connecting circles indicates a common occurrence of rugosan genera in the different areas.

recognizing the late Llandovery in the Xiushan Formation which yields Nanshanophyllum. Therefore, the conodont date from the Fukata Formation and occurrences of Nanshanophyllum and Shensiphyllum from the Middle Member of the Gionyama Formation indicate that the geological age of the Middle Member should extend downward to, at least, the late Llandovery. The other corals from the Middle Member have relatively long geologic ranges, from the late Llandovery to the early Ludlow at least. The range of these corals is also supported by conodont date from the Fukata Formation.

A comparison of the Silurian rugose corals from the Gionyama area with those from other Japanese localities is presented in Fig. 5. The corals, Kodonophyllum, Pycnostylus and Zelophyllum, which were reported by Hamada (1961) from his G3 facies limestone, are added in the list of rugose corals from the Gionyama area. Rugose coral genera from the Kurosegawa Terrane have been compared with those from other Silurian localities in the Hida 'Gaien' Belt and the South Kitakami Terrane (Hamada 1961, Kido \& Sugiyama 2005). Kato et al. (1980) reported Rhizophyllum from the Hitoegane limestone in the Fukuji area of the Hida 'Gaien' Belt, and Kobayashi \& Hamada (1974)

\begin{tabular}{|c|c|c|c|c|c|}
\hline \multirow[b]{2}{*}{$\begin{array}{l}\text { Rugose } \\
\text { coral genera }\end{array}$} & \multirow{2}{*}{ 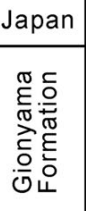 } & \multicolumn{3}{|c|}{ South China } & \multirow{2}{*}{ 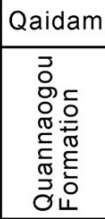 } \\
\hline & & 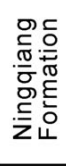 & 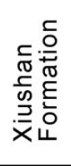 & 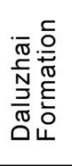 & \\
\hline Rhabdocyclus & & & & $\square$ & \\
\hline Aphyllum & & $\square$ & & & \\
\hline Maikottia & & $\square$ & & & \\
\hline Cysticonophyllum & & $\square$ & & & \\
\hline Hedstroemophyllum & & $\square$ & & & \\
\hline Microplasma & & $\square$ & & & \\
\hline Nipponophyllum & & $\square$ & & & \\
\hline Pilophyllia & & $\square$ & & $\square$ & \\
\hline Mucophyllum & & $\square$ & & & \\
\hline Gyalophylloides & & $\square$ & & $\square$ & \\
\hline Gyalophyllum & & $\square$ & $\square$ & & \\
\hline Ceriaster & & $\square$ & & & \\
\hline Kyphophyllum & & $\square$ & & & $\square$ \\
\hline Micula? & & $\square$ & & & \\
\hline Miculiella & & $\square$ & & & \\
\hline Pseudophaulactis & & & & $\square$ & \\
\hline Chonophyllum & & $\square$ & & & \\
\hline Idiophyllum & & $\square$ & & & \\
\hline Dinophyllum & & $\square$ & & & $\square$ \\
\hline Ningqiangophyllum & & $\square$ & & & \\
\hline Dokophyllum & & $\square$ & & & \\
\hline Tabularia & & $\square$ & & $\square$ & \\
\hline Oliveria & & $\square$ & & $\square$ & \\
\hline Tryplasma & 0 & $\square$ & & & $-\square$ \\
\hline Cystiphyllum & 0 & $\square$ & & & $\square$ \\
\hline Holmophyllum & 0 & $-\square$ & & & \\
\hline Labechiellata & O- & $-\square$ & & & \\
\hline Rhizophyllum & 0 & $\square$ & & & \\
\hline Kodonophyllum & 0 & $\square$ & & & \\
\hline Neobrachyelasma & 0 & $\square$ & & & \\
\hline Pseudamplexus & 0 & $\square$ & & & \\
\hline Amsdenoides & 0 & $\square$ & & & \\
\hline Pycnostylus & 0 & $\square$ & & & \\
\hline Zelophyllum & 0 & $\square$ & & $-\square$ & $\square$ \\
\hline Amplexoides & 0 & $-\square$ & & & \\
\hline Strombodes & 0 & $-\square$ & & & \\
\hline Nanshanophyllum & 0 & $\square$ & $\square-$ & $-\square$ & $\square$ \\
\hline Shensiphyllum & 0 & $\square$ & & $\square$ & \\
\hline Ptychophyllum & 0 & $\square$ & & & \\
\hline
\end{tabular}

Figure 6. Rugose corals from the Gionyama Formation and the Telychian strata in South China and Qaidam, from Hamada (1961), Chen et al. (1991), Scrutton \& Deng (2002), He \& Chen (2004), Chen et al. (2005), and this study. Circles or squares indicate coral occurrences in the Gionyama Formation or in the Telychian strata in China, respectively. Lines connecting circles and squares indicate a common occurrence of rugosan genera between the Gionyama Formation and the Telychian strata in China.

reported the trilobite Encrinurus from this unit in this region. Based on these fossils, the age of this limestone was considered to be late Silurian (Kato et al. 1980). However, Kurihara (2004) pointed out that the Hitoegane limestone is a xenolith in a serpentinite. Thus, relationship between the corals in the Gionyama Formation and this limestone is questionable. A comparison of rugose coral genera from the Kawauchi Formation in the Hikoroichi area of the 


\begin{tabular}{|c|c|c|c|c|c|}
\hline Formation or & Japan & & astern & Austra & \\
\hline $\begin{array}{l}\text { Rugose } \\
\text { coral genera }\end{array}$ & 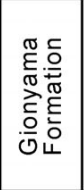 & 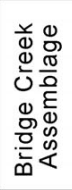 & 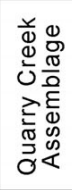 & 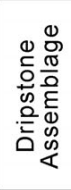 & 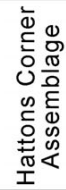 \\
\hline Primitophyllum? & & $\square$ & & & \\
\hline $\begin{array}{l}\text { Cantrillia } \\
\text { Aphyllum }\end{array}$ & & $\square$ & $\square$ & 口 & $\square$ \\
\hline Stortophyllum & & & $\bar{\square}$ & & \\
\hline Cysticonophyllum & & $\square$ & & & \\
\hline $\begin{array}{l}\text { Hedstroemophyllum } \\
\text { "Microplasma" }\end{array}$ & & & $\begin{array}{l}\square \\
\square\end{array}$ & $\square$ & $\square$ \\
\hline Coronoruga & & & & $\square$ & \\
\hline Nipponophyllum & & & & $\square$ & $\square$ \\
\hline Lambeophyllum? & & $\square$ & & & \\
\hline Streptelasma & & $\square$ & & & \\
\hline Plektelasma & & & $\square$ & & \\
\hline Grewingkia & & $\square$ & $\square$ & & \\
\hline Cystipaliphyllum & & $\square$ & & & \\
\hline $\begin{array}{l}\text { Dinophyllum } \\
\text { Palaeocyathus }\end{array}$ & & & & $\square$ & $\square$ \\
\hline Spinocarina & & & $\square$ & & \\
\hline Mucophyllum & & & & & $\square$ \\
\hline Stylopleura & & & & $\square$ & $\square$ \\
\hline Multicarinophyllum & & & & & $\square$ \\
\hline Palaeophyllum & & & $\square$ & $\square$ & \\
\hline Multicarinophyllum & & & & $\square$ & \\
\hline Lindstroemophyllum? & & & $\square$ & & \\
\hline $\begin{array}{l}\text { Pilophyllum } \\
\text { Detilasma }\end{array}$ & & $\square$ & $\square$ & $\square$ & \\
\hline Dokophyllum & & & $\square$ & & $\square$ \\
\hline Ketophylloides? & & $\square$ & & & \\
\hline Tabularia & & $\square$ & & & \\
\hline Mictocystis & & & $\square$ & & \\
\hline Yassia & & & & & $\square$ \\
\hline $\begin{array}{l}\text { Entelophyllid } \\
\text { Entelophyllum }\end{array}$ & & & $\square$ & $\square$ & $\square$ \\
\hline Angullophyllum & & & $\square$ & & \\
\hline Arachnophyllum & & & $\square$ & $\square$ & \\
\hline $\begin{array}{l}\text { Idiophyllum } \\
\text { Zenophila }\end{array}$ & & & & & $\square$ \\
\hline Bungoniella & & & & $\square$ & \\
\hline Amplistela & & & $\square$ & & \\
\hline Phaulactis & & & $\square$ & $\square$ & $\square$ \\
\hline Neomphyma? & & & $\square$ & & \\
\hline Toquimaphyllum & & & & & $\square$ \\
\hline Cyathactis & & & $\square$ & & \\
\hline Zelolasma? & & & & & $\square$ \\
\hline Burota & & & $\square$ & & \\
\hline Tryplasma & 0 & $-\square$ & $-\square$ & $-\square$ & $\square$ \\
\hline Cystiphyllum & 0 & $-\square$ & $-\square$ & & \\
\hline Holmophyllum & 0 & & $\square$ & & \\
\hline Labechiellata & 0 & & $\square$ & $\square$ & \\
\hline Rhizophyllum & 0 & & $-\square$ & & $\square$ \\
\hline Kodonophyllum & 0 & & & & \\
\hline Neobrachyelasma & $\mathrm{O}$ & & & & \\
\hline Pseudamplexus & 0 & & $\square$ & & \\
\hline Amsdenoides & 0 & & & & \\
\hline Pycnostylus & 0 & & $\square$ & $-\square$ & $\square$ \\
\hline Zelophyllum & O & & & & \\
\hline Amplexoides & 0 & $-\square$ & $\square$ & & \\
\hline Strombodes & $\mathrm{O}$ & & $\square$ & & \\
\hline Nanshanophyllum & $\mathrm{O}$ & & & & \\
\hline Shensiphyllum & 0 & & & & \\
\hline Ptychophyllum & 0 & & & $\square \square$ & $\square \square$ \\
\hline
\end{tabular}

South Kitakami Terrane with those in the Gionyama Formation shows that there are five genera in common: Tryplasma, Cystiphyllum, Labechiellata, Rhizophyllum, and Amsdenoides. There are no rugose coral genera in the South Kitakami Terrane that indicate a late Llandovery age. It seems more reasonable to suggest that the Kawauchi Formation is Wenlock to Ludlow in age.

\section{Paleobiogeographic implications}

Based on the occurrences of the tabulate corals such as Falsicatenipora and Schedohalysites from the Kurosegawa and South Kitakami terranes, some affinities between the Japanese Silurian corals and those from South China and Australia were suggested by Hamada (1961) and Kato (1990). According to Hill (1981) and Scrutton \& Deng (2002), Falsicatenipora occurs in the upper Llandovery of Ningqiang-Guangyuan area in South China and the Wenlock to Ludlow of New South Wales and Queensland, eastern Australia. Schedohalysites is reported from the upper Llandovery of New South Wales, Australia and the Ningqiang-Guangyuan area, and from the Wenlock to Ludlow of China, Australia, India, and Gotland (Hill 1981). However, Young \& Elias (1995) and Mõtus (2005) mentioned that the morphological definition of Schedohalysites by Hamada (1957) was questionable. Further consideration of biotic affinity based on this tabulate coral requires more careful taxonomic study.

Niko \& Adachi $(2000,2004)$ reported the tabulate corals, Mesosolenia decorasa and Egosiella sp. cf. E. ningqiangensis, from the Gionyama Formation, which also occurred in the Silurian of the Daba Shan Mountains in the Sichuan-Shaanxi border area. They suggested an affinity of tabulate coral faunas between the Gionyama Formation and the Daba Shan Mountains.

Kato (1990) reported compound rugose corals, Nipponophyllum and Labechiellata, together with the tabulate corals like halysitids and favositids, from the Kawauchi Formation and suggested that these compound corals could indicate the location of paleo-equator during the Silurian and stated that the tropical distribution of these corals was parallel to the paleo-equator during the Wenlock.

The biostratigraphy and sedimentary facies of the Lower Silurian of China were revised precisely based on occurrences of conodonts and graptolites, and the Silurian

Figure 7. Rugose corals from the Gionyama Formation compared to the four coral assemblages which are recognized in eastern Australia (Pickett 1982, Pickett et al. 2000, Strusz \& Munson 1997). Circles or squares indicate Silurian rugosan genera in the Gionyama Formation or in the coral assemblages of eastern Australia. 
paleogeography in China was adjusted based on these revisions (Rong \& Chen 2003, Scrutton \& Deng 2002). Furthermore, these revisions resulted in new lists of coral occurrences for each locality and each stratigraphic unit in the Silurian of China. The rugose corals from the Gionyama Formation are similar to those from the upper Llandovery strata of South China (see Fig. 6). All the rugose coral genera from the Gionyama Formation occur in the Ningqiang Formation of the Ningqiang-Guangyuan area at the northwestern margin of the South China Block. Some genera from the Gionyama Formation also occur in the upper Llandovery of the Xiushan and Daluzhai formations of South China, and the Quannaogou Formation of Qaidam (Fig. 6). Additionally, 13 genera of tabulate corals among 38 genera reported from the Ningqiang Formation also occur in the Gionyama Formation (Hamada 1961; Niko \& Adachi 2000, 2004; Scrutton \& Deng 2002).

The Gionyama Formation yields rugosan genera that are also documented from equivalent formations in Tarim and North China. A comparison of rugosan genera from the Wenlock to Ludlow of Tarim (Wang et al. 2001) with those from the Gionyama Formation shows that in both areas same five genera appear. They are Tryplasma, Cystiphyllum. Zelophyllum, Amplexoides and Ptychophyllum. Six genera such as Tryplasma, Holmophyllum, Zelophyllum, Amplexoides, Strombodes and Ptychophyllum from the Gionyama Formation are also known from the Wenlock and upper Silurian of North China (Guo 1976, 1980; Li et al. 1985). On the other hand, the rugose corals from the Llandovery to Ludlow of Hainan, Tibet and West Sichuan-East Xizhang region seem to have only a few genera in common with those from the Gionyama Formation (Deng \& Zhang 1984, Wang et al. 2005, Wu et al. 1982).

The rugose coral genera from the Gionyama Formation also commonly occur in the Silurian of Australia. Four successive coral assemblages in the Silurian of New South Wales and Queensland, eastern Australia are recognized (Pickett 1982, Pickett et al. 2000, Strusz \& Munson 1997). They are the Bridge Creek assemblage (early to middle Llandovery), the Quarry Creek assemblage (late Llandovery to early Wenlock), the Dripstone assemblage (early Wenlock to early Ludlow), and the Hattons Corner assemblage (early Ludlow to Přídolí) in ascending order. The Gionyama Formation includes nine genera that are known in the Quarry Creek assemblage and four genera that are documented in the Dripstone assemblage (see Fig. 7).

The present study reveals that the rugose corals from the Gionyama Formation include both cosmopolitan genera and endemic genera such as Shensiphyllum, Nanshanophyllum, which occur only in South China, Qaidam and Japan. The occurrences of Shensiphyllum and Nanshanophyllum from the Gionyama Formation may indicate that a paleogeographic connection between the South China Block and Kurosegawa Terrane existed dur- ing the Silurian. The genus Shensiphyllum is characterized by having a fasciculate corallum with carinate septa that swell into a lenticular shape at the boundary of tabularium and dissepimentarium, tabularium divided into convex inner and concave outer series, and dissepimentarium including a one row of longitudinal series of horseshoe dissepiments (Kido 2009a). In China, ten species which occurred in the Ningqiang Formation (Shaanxi-Sichuan), Shamao Formation (Hubei), Daluzhai Formation (Northeast Yunnan) and Wangjiawan Formation (Sichuan) were assigned to Shensiphyllum (Chen et al. 2005, Ge \& Yü 1974, He 1978, Li et al. 1975, Scrutton \& Deng 2002, Tang 2006). Among them, the species except for the one from the Wangjiawan Formation have one series of horseshoe dissepiments with a few series of subglobose or elongate dissepiments within dissepimentarium. In the species such as Shensiphyllum aggregatum Ge \& Yü, 1974 (type species of the genus) and S. guangyuaense He, 1978 from the Ningqiang Formation, and S. minor Chen, He \& Tang, 2005 from the Daluzhai Formation one series of horseshoe dissepiments is developed in the outer part of dissepimentarium. One series of horseshoe dissepiments in Shensiphyllum phacelloides (Cao in Li et al. 1975) and Shensiphyllum sp. reported by Scrutton \& Deng (2002) from the Ningqiang Formation, and S. hubeiense (Wu in Jia $\& \mathrm{Wu}$ 1977) from the Shamao Formation occurs in the middle part of dissepimentarium. Kido (2009a) indicated that the location of one series of horseshoe dissepiments within the dissepimentarium could be used to separate these species into two different groups. Three species described by Tang (2006) from the Wangjiawan Formation, Shensiphyllum intermedium Tang, 2006, S. proliferum Tang, 2006 and S. simplex Tang, 2006, may be also assigned to an other group which is related to the staurioid rugose corals. The dissepimentarium in Shensiphyllum intermedium is composed of one row of horseshoe dissepiments and one to two rows of subglobose, small dissepiments developed in the outer or inner side of them in the single corallum. Shensiphyllum proliferum has one row of horseshoe dissepiments which are irregularly accompanied by one to two rows of subglobose, declined dissepiments in the outer or inner side of them. The dissepimentarium in Shensiphyllum simplex is generally composed of one series of horseshoe dissepiments, but in some corallites longitudinal series of flat dissepiments are developed between them and the wall. Shensiphyllum sp. (see Kido 2009a, figs 11.9-11.13, 12) which occurs in the Gionyama Formation is characterized by possessing one row of horseshoe dissepiments in the outer part of the dissepimentarium, as well as $S$. aggregatum, S. guangyuaense and S. minor. Only these four species are assigned to Shensiphyllum here.

Nanshanophyllum was previously restricted to the upper Llandovery of South China (Shaanxi-Sichuan, Northeast Yunnan, Hunan and Southeast Gansu) and Qaidam 
A

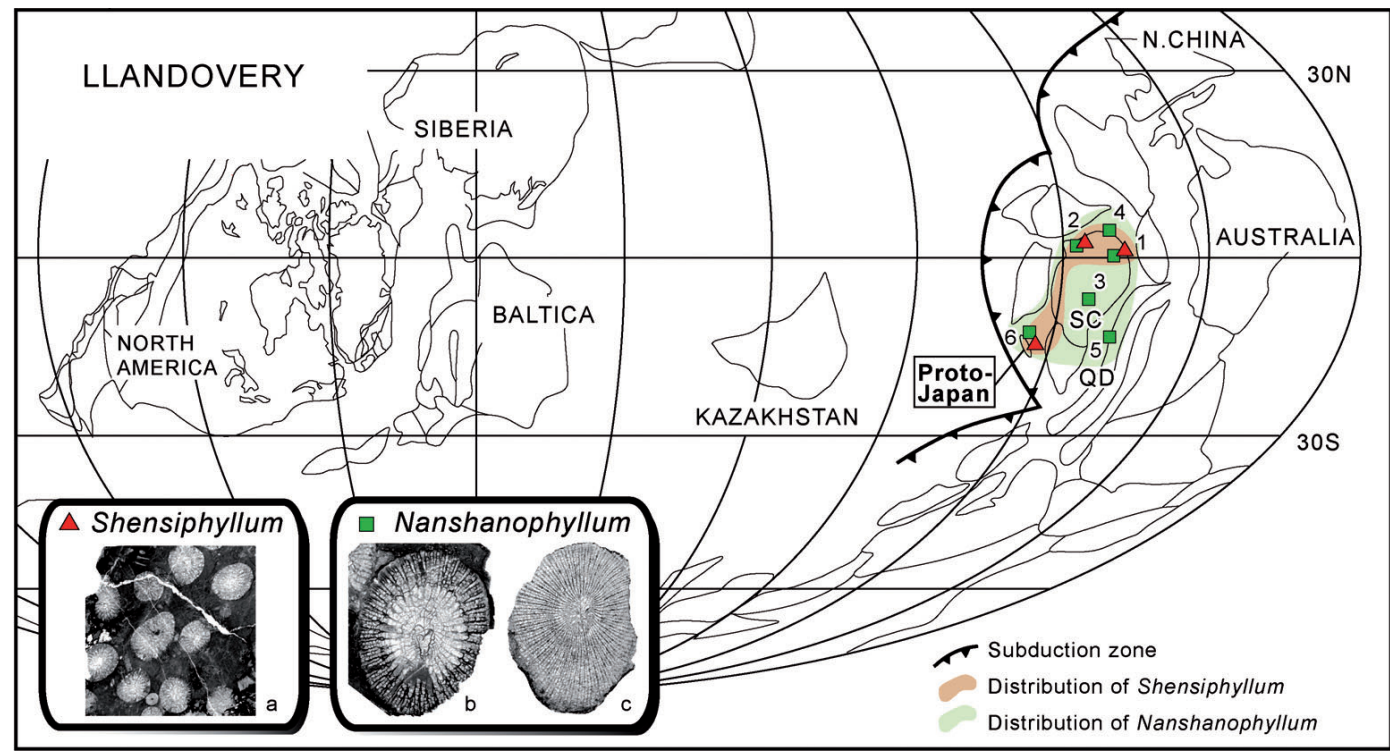

B

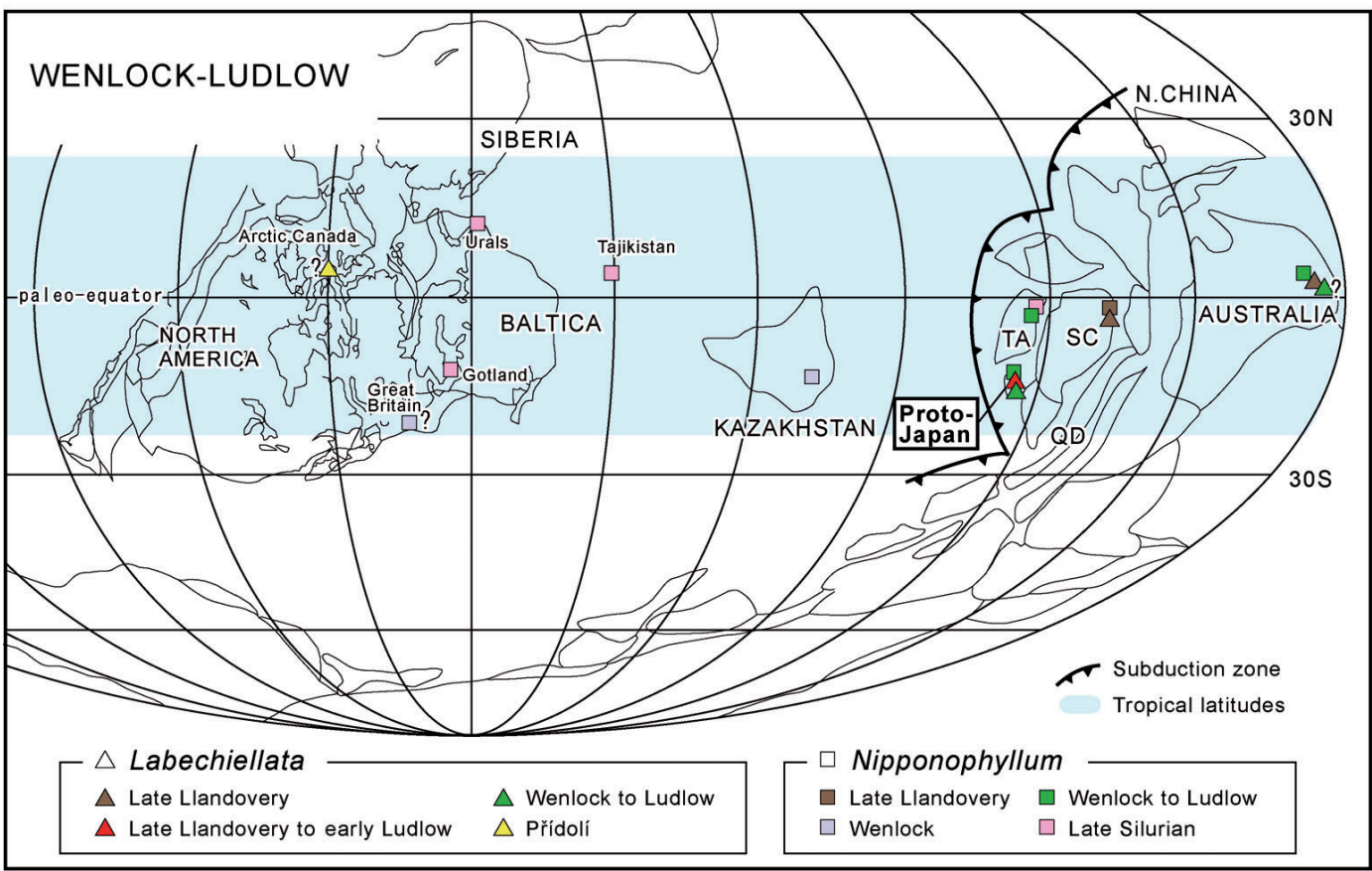

Figure 8. A - paleogeographic distribution of Shensiphyllum and Nanshanophyllum during the late Llandovery. Triangles with red color indicate the locations of Shensiphyllum and squares with green color indicate the locations of Nanshanophyllum. 1. Ningqiang-Guangyuan (Shaanxi-Sichuan), 2. Daguan (NE Yunnan), 3. Shimen (Hunan), 4. Zhugqu (SE Gansu), 5. Yumen (NW Gansu), 6. Kurosegawa Terrane. a - Shensiphyllum sp. GF. D 25039-1, Loc. KL1, Gionyama Formation, b - Nanshanophyllum hamadai. GF. D 25006a, Loc. KL2, Gionyama Formation, c - N. gokasense. GF. D 25028, KL1, Gionyama Formation. • B - paleogeographic distribution of Labechiellata and Nipponophyllum. Triangles indicate the locations of Labechiellata and squares indicate the locations of Nipponophyllum. Different ages are shown by different colors in triangles and squares. Abbreviations: SC - South China, QD - Qaidam, TA - Tarim. The geographical range of the tropical latitudes is based on Kiessling et al. (2003). Llandovery and Wenlock-Ludlow paleo-maps are modified from Golonka (2002) and Kiessling et al. (2003).

(Northwest Gansu). Hill (1981) considered Nanshanophyllum as a solitary coral with carinate septa and included the following three species in Nanshanophyllum: Stereoxylodes multicarinatus and Stereoxylodes? sp. described by McLean (1975) from the upper Llandovery of New South Wales, Australia and Stereoxylodes
(Nanshanophyllum) sp. described by Pedder (1976) from the Upper Silurian (Přídolí) of Arctic Canada. However, Nanshanophyllum is distinguishable from those species in having bilateral symmetry in septal arrangement and a "pseudo"-axial structure (Kido 2009a, figs 6, 8, 10, 11.1-11.8). Morphologically Nanshanophyllum hamadai 
and $N$. gokasense from the Gionyama Formation resemble $N$. typicum and $N$. mirandum which were described by Yü (1956, 1962) from the Quannaogou Formation of Northwest Gansu, respectively (for detailed taxonomy see Kido 2009a).

Neobrachyelasma is also expected to be an endemic taxon. It is known from the: (1) upper Llandovery of Sichuan and Hubei, South China (Cao \& Lin 1982, Chen et al. 2005, Scrutton \& Deng 2002), (2) Wenlock to Ludlow of the Altai, southwest Siberia (Ivanovskiy \& Kulkov 1974, Zheltonogova 1965), and (3) Ludlow of Balkhash, Kazakhstan (Nikolaeva 1960, Sytova 1966). In addition, Dinophyllum stokesi and D. estonicum described by Sultanbekova (1986) from the lower Llandovery of Kazakhstan should be assigned to Neobrachyelasma. Figured materials of these two species have twisted major septa and incomplete tabulae with concave floors in the axial area, a characteristic of Neobrachyelasma. Neobrachyelasma japonica (Kido 2010, figs 3, 4.1-4.6, 6) from the Gionyama Formation shows similarity with specimen from the upper Llandovery of South China. Perhaps Neobrachyelasma appeared in Kazakhstan during the early Llandovery, migrated to South China and Japan (Gionyama area) in the late Llandovery, and then to Siberia during the Wenlock to Ludlow. The interpretation of the migration of Neobrachyelasma may also suggest paleogeographic proximity between the South China and the Kurosegawa Terrane during the late Llandovery (Kido 2010).

Cosmopolitan coral genera of the Gionyama Formation including Tryplasma, Cystiphyllum, Holmophyllum, Labechiellata, Rhizophyllum, Pseudamplexus, Amsdenoides, Amplexoides, Strombodes, and Ptychophyllum commonly occur in South China, Qaidam, North China, Tarim, Kazakhstan, Gotland, Siberia, eastern Australia, and North America. Amplexoides sp. aff. A. chaoi (Kido 2010, figs $4.11-4.17,9$ ) in the Gionyama Formation is similar to A. chaoi reported from the Lower Silurian of South China (Hubei, Guizhou and Southeast Gansu). Among the holmophyllids in the Gionyama Formation, Holmophyllum? sp. seems to have some similarities to the species which occur in the upper Llandovery and ?lower Ludlow of eastern Australia (New South Wales), the Wenlock and Upper Silurian of China (Xinjiang and Inner Mongolia), and the Silurian of North America (Maine). Another holmophyllid, massive thamnasterioid coral, Labechiellata, is known in Japan (South Kitakami and Kurosegawa terranes), upper Llandovery of China (ShaanxiSichuan), upper Llandovery, ?Wenlock and ?Ludlow of eastern Australia (New South Wales), Lower Devonian of Central Kazakhstan, and possibly ?Př́idolí of Arctic Canada. The Gionyama species has close similarities with Labechiellata currani (Wright in Wright \& Bauer 1995) from New South Wales of eastern Australia (see Kido 2009b). The affinities of species like Amplexoides,
Holmophyllum and Labechiellata in the Gionyama Formation may indicate a paleobiogeographic relation between 'Proto-Japan' and those other areas where similar species occur.

Paleogeographic distributions of the endemic genera, Shensiphyllum and Nanshanophyllum, are plotted on the Llandovery paleo-map as shown in Fig. 8A. Additionally, cosmopolitan genera which occur as compound forms, such as Labechiellata and Nipponophyllum, are plotted on the Wenlock to Ludlow paleo-map in Fig. 8B. Nipponophyllum appears in Northeast Japan (South Kitakami Terrane), upper Llandovery of Shaanxi, China, Wenlock of Kazakhstan, ?Wenlock of Great Britain, upper Wenlock, lower or middle Ludlow of New South Wales, Australia, upper Ludlow of Eastern Urals and Gotland, Sweden, and the Upper Silurian of Tajikistan (Kato 1982). Recently, Wang et al. (2001) also reported the occurrence of this genus from the Wenlock to Ludlow and the Prídolí of Xinjiang (South Tianshan region), China. In the Silurian of the Kurosegawa and South Kitakami terranes, tabulate corals such as favositids and halysitids commonly occur together with compound holmophyllid rugose corals. These compound corals may indicate tropical environments as proposed by Kato (1990) and suggest that 'Proto-Japan' was located in sub-tropical to tropical latitudes during the Silurian, together with the other areas that yield these corals (see Fig. 8B).

The paleo-maps shown in Fig. 8 are based on Golonka (2002) and Kiessling et al. (2003). According to them, the South China Block, as well as Qaidam and Tarim, was located at low latitude near the equator in the southern hemisphere during the Silurian (Llandovery to Ludlow). At the same time the North China Block which does not share any of the endemic taxa presented here, was located near the middle latitudes of northern hemisphere. Thus, the South China Block was far from the North China Block during the Silurian.

The occurrences of rugose corals in the Gionyama Formation and the currently understood paleobiogeography of the Silurian suggest the possibility that 'Proto-Japan' was located at the subduction zone that developed near the edge of the South China Block in the Early Silurian. It is also suggested that there might have been a Silurian connection, via an ocean current system, between the Kurosegawa Terrane and the South China Block, Qaidam, Tarim, Kazakhstan, Tajikistan, Siberia, Baltica, North America, and Australia within a zone near the paleo-equator.

\section{Conclusions}

1. Careful taxonomic studies revealed that the Middle Member of the Gionyama Formation contains abundant rugose corals representing 18 species in 13 genera. 
2. The geological age of the Middle Member of the Gionyama Formation ranges from the late Llandovery to the early Ludlow based on the rugose corals.

3. All of the rugose genera found in the Gionyama Formation also occur in the Ningqiang Formation at the northeastern part of the South China Block.

4. The rugose corals from the Gionyama Formation include both cosmopolitan genera and endemic genera. The endemic genera may indicate paleogeographic proximity between the Kurosegawa Terrane and the South China Block.

5. Cosmopolitan genera suggest that, during the Silurian, the Kurosegawa Terrane occurred in a zone parallel to the paleo-equator.

6. Paleobiogeographic interpretation based on the rugose corals from the Gionyama Formation indicates that 'Proto-Japan' probably was located at the subduction zone along the edge of the South China Block during the Silurian.

\section{Acknowledgements}

The first author is grateful for financial support by the Chinese National 973 Project 2006CB806400, National Natural Science Foundation of China and Chinese Academy of Sciences. Initial field survey in Japan was supported by the Board of Education, Gokase-cho Town Hall. Makoto Kato (Hokkaido University), Zhanqiu Deng and Xiangdong Wang (Nanjing Institute of Geology and Palaeontology, Chinese Academy of Sciences) offered useful information concerning Silurian rugose corals. Kei Mori (Tohoku University), Koichi Nagai (Fukuoka, Japan) and Toshio Kawamura (Miyagi University of Education) provided helpful comments on the stratigraphy and sedimentology of the Gionyama Formation. Ronald R. West (Kansas State University) gave useful suggestions on an early version of the manuscript. Three reviewers, Xu Chen (Nanjing Institute of Geology and Palaeontology), Robert J. Elias (University of Manitoba) and Graham A. Young (Manitoba Museum), provided constructive comments. The authors are deeply grateful to all of them.

\section{References}

Adachi, T. \& Niko, S. 1996. Some Silurian tabulate corals from the Gionyama Formation, Miyazaki Prefecture. Chigakukenkyu 45(2), 67-73. [in Japanese]

CaO, X.D. \& Lin, B.Y. 1982. Rugosa, 15-50. In XI' an Institute of Geology and Mineral Resource (ed.) Palaeontological Atlas of Northwest China, Shaanxi-Guansu-Ningxia Volume, Part 1, Pre Cambrian and early Palaeozoic. Geological Publishing House, Beijing. [in Chinese]

Chen, X., Rong, J.Y., Wu, H.J., Deng, Z.Q., Wang, C.Y., Xu, J.T., Qiu, J.Y., Geng, L.Y., Chen, T.E., Hu, Z.X., WANG, S.Q.
\& LI, J. 1991. The Silurian rocks between Guangyuan of Sichuan and Ningqiang of Shaanxi. Journal of Stratigraphy 15(1), 1-25. [in Chinese with English abstract]

Chen, J.Q., He, X.Y. \& TANG, L. 2005. Early Silurian (Telychian) rugose coral fauna of Daguan area, Northeast Yunnan. Acta Palaeontologica Sinica 44(2), 229-246. [in Chinese with English summary]

Deng, Z.Q. \& Zhang, Y.S. 1984. Paleozoic corals from Hengduan Mountains, Southwestern China, 1-102. In REGIONAL Geological Surveying Team, Sichuan Province \& Nanjing Institute of Geology and PALAeontology (eds) Stratigraphy and Palaeontology in W. Sichuan and E. Xizang, China Part 4. Sichuan Science and Technology Press, Chengdu. [in Chinese]

GE, Z.Z. \& YÜ, C.M. 1974. Silurian corals, 165-173. In NANJING Institute of Geology and Palaeontology (ed.) A handbook of the stratigraphy and paleontology of southwest China. Academia Sinica, Science Press, Beijing. [in Chinese]

Golonka, J. 2002. Plate-tectonic maps of the Phanerozoic, 21-75. In Kiessling, W., Flügel, E. \& Golonka, J. (eds) Phanerozoic reef patterns. Society of Economic Paleontologists and Mineralogists Special Publication 72.

Grabau, A.W. 1925. Summary of the faunas from the Sintan shale. Bulletin of the Geological Survey of China 7, 77-85.

Guo, S.Z. 1976. Tetracoralla, 63-101. In ResEARCH Institute oF Geological Science of the Northeast \& Bureau of the InNer Mongolian Autonomous Region (eds) Atlas of Paleontology of the North China region, Inner Mongolia 1. Geological Publishing House, Beijing. [in Chinese]

Guo, S.Z. 1980. Tetracoralla, 106-153. In Shengyang Institute of Geology and Mineral Resources (ed.) Paleontological Atlas of Northeast China. Geological Publishing House, Beijing. [in Chinese]

Hamada, T. 1957. On the classification of the Halysitidae, II. Journal of the Faculty of Science, the University of Tokyo Sec. 2, 10, 407-430.

Hamada, T. 1959. Gotlandian stratigraphy of the Outer Zone of Southwest Japan. Journal of the Geological Society of Japan 65, 770, 688-700. [in Japanese with English abstract]

Hamada, T. 1961. The Middle Paleozoic Group of Japan and its bearing on her geological history. Journal of the Faculty of Science, the University of Tokyo Sec. 2, 13, 1-79.

He, X.Y. \& CHEN, J.Q. 2004. Origin, dispersal and biogeographic affinity of the Middle-Late Ordovician and the Llandovery rugose corals in the Yangtze region. Acta Palaeontologica Sinica 43(2), 179-191.

He, Y.X. 1978. Rugosa, 98-179. In Chengdu Institute of Geology And Mineral Resources (ed.) Atlas of fossils of Southwest China, Sichuan volume, part 1. Geological Publishing House, Beijing. [in Chinese]

Hill, D. 1981. Coelenterata, Pt. F, supplement 1, Rugosa and Tabulata, 762 pp. In Teichert, C. (ed.) Treatise on Invertebrate Paleontology, vols 1 and 2. The Geological Society of America \& The University of Kansas, Boulder, Colorado \& Lawrence, Kansas.

IsOZAKI, Y. 1998. Origin and growth of accretionary orogen of the Japanese Islands: From birth at rift zone to Miyashiro-type orogeny. Memoirs of the Geological Society of Japan 50, 89-106. [in Japanese with English abstract] 
IvanovskiY, A.B. \& Kulkov, N.P. 1974. Rugozy, brakhiopody i stratigrafiya silura Altai-Sayanskoi gornoi oblasti. Trudy Instituta Geologii i Geofiziki, Sibirskoe Otdelenie, Akademiya Nauk SSSR 231, 1-122.

JiA, H.Z. \& Wu, J.Z. 1977. Class Anthozoa, 9-24. In Hubei InstitUTE OF GeOlogical SCIENCE et al. (eds) The Palaeontological Atlas of South-Central China. Part 1. Geological Publishing House, Beijing. [in Chinese]

Kanbe, N. 1957. Explanatory Text of the Geological Map of "Kuraoka" (1/50000). 51 pp. Geological Survey of Japan. [in Japanese with English abstract]

Kato, M. 1982. Nipponophyllum (Rugosa) from Gotland. Stockholm contributions in Geology 37, 117-128.

Kato, M. 1990. Palaeozoic corals, 307-312. In IchIKAWA, K., Mizutani, S., Hara, I., Hada, S. \& Yao, A. (eds) Pre-Cretaceous terranes of Japan. Publication of IGCP Project No. 224: Pre-Jurassic Evolution of East Asia. Osaka City University, Osaka.

Kato, M., Minato, M., Niikawa, I., Kawamura, M., Nakai, H. \& HAGA, S. 1980. Silurian and Devonian corals of Japan. Acta Paleontologica Polonica 25(3-4), 557-566.

Kawamura, T., Takano, Y., Adachi, N., Ezaki, Y. \& Sugiyama, T. 2003. Stratigraphy and microfacies characteristics of the Silurian carbonates in the Kurosegawa Terrane. Abstract of the $110^{\text {th }}$ Annual Meeting of the Geological Society of Japan 78. [in Japanese]

KIDO, E. 2009a. Nanshanophyllum and Shensiphyllum (Silurian Rugosa) from the Kurosegawa Terrane, Southwest Japan, and their paleobiogeographic implications. Journal of Paleontology 83(2), 280-292. DOI 10.1666/08-113.1

KIDO, E. 2009b. Silurian Holmophyllidae (Rugosa) from the Gionyama Formation of the Kurosegawa Terrane, Southwest Japan. Paleontological Research 13(3), 293-306. DOI 10.2517/1342-8144-13.3.293

KidO, E. 2010. Silurian rugose corals from the Kurosegawa Terrane, Southwest Japan, and the first occurrence of Neobrachyelasma. Journal of Paleontology 84(3), 466-476. DOI 10.1666/09-037.1

Kido, E. \& Sugryama, T. 2005. Silurian rugose corals from the Gionyama Formation, Gokase-cho, Miyazaki Prefecture, Southwest Japan. Fukuoka University Science Reports 35(1), 11-29. [in Japanese with English abstract]

Kido, E. \& SugiYama, T. 2007. Reexamination of the stratigraphy of the Silurian-Devonian and Carboniferous strata in the Gionyama area, Gokase-cho, Miyazaki Prefecture. Proceeding of Nishinihon Branch of the Geological Society of Japan 153, O-17. [in Japanese]

Kiessling, W., Flügel, E. \& Golonka, J. 2003. Patterns of Phanerozoic carbonate platform sedimentation. Lethaia 36(3), 195-225. DOI 10.1080/00241160310004648

Kobayashi, T. \& HamadA, T. 1974. Silurian trilobites of Japan in comparison with Asian, Pacific and other regions. Palaeontological Society of Japan, Special Papers 18, $1-155$.

Kobayashi, T. \& Hamada, T. 1988. Present status of studies on Silurian trilobites and cephalopods in Japan. Journal of Geography 97(6), 543-554. [in Japanese with English abstract]

KuriHARA, T. 2004. Silurian and Devonian radiolarian biostratigraphy of the Hida Gaien belt, central Japan. Journal of the
Geological Society of Japan 110(10), 620-639. [in Japanese with English abstract]

Kurihara, T. \& SASHida, K. 1998. Occurrence and significance of the Late Silurian and Early to Middle Devonian radiolarians from the Kuzuryu Lake district of the Hida Gaien Belt, Fukui Prefecture, central Japan. Journal of the Geological Society of Japan 104(12), 845-858. [in Japanese with English abstract]

Kuwano, Y. 1976. Finding of Silurian conodont assemblages from the Kurosegawa Tectonic Zone in Shikoku, Japan. Memoirs of the National Science Museum 9, 17-22. [in Japanese with English summary]

Li, W.G., Rong, J.Y., Dong, D.Y., Yang, D.R., Su, Y.Z. \& WANG, Y.F. 1985. Silurian and Devonian rocks of the Bateaobao area in Darhan Mumingan Joint Banner, Inner Mongolia, 1-25. In LI, W.G., Rong, J.Y. \& Dong, D.Y. (eds) Silurian and Devonian rocks and faunas of the Bateaobao area in Darhan Mumingan Joint Banner, Inner Mongolia. The People's Publishing House of Inner Mongolia. [in Chinese with English summary]

Li, Y.X., CAO, X.D., SonG, L.S., Zhou, Z.Q. \& Yang, J.Y. 1975. Silurian corals, 179-221. In LI, Y.A., Song, L.S., ZHou, Z.Q. \& YAng, J.Y. (eds) The Lower Palaeozoic stratigraphy of western Dabashan. Geological Printing House, Beijing. [in Chinese]

MCLEAN, R.A. 1975. Lower Silurian rugose corals from central New South Wales. Journal and Proceedings, Royal Society of New South Wales 108, 54-69.

MõTus, M.A. 2005. Silurian (Llandovery-Wenlock) tabulate corals of Baltoscandia: taxonomy, palaeoecology, distribution. Dissertationes Geologicae Universitatis Tartuensis 17, $1-166$.

Niko, S. 1998. Silurian tabulate corals Eofletcheria and Aulocystis from the Gionyama Formation, Miyazaki Prefecture. Bulletin of the National Science Museum, Tokyo, Series C 24, 41-49.

Niko, S. \& ADACHI, T. 1999a. Gokaselites, a new genus of Silurian tabulate corals from the Gionyama Formation, Miyazaki Prefecture. Bulletin of the National Science Museum, Tokyo, Series C 25, 45-49.

Niko, S. \& Adachi, T. 1999b. Silurian Pachyporicaes (Coelenterata: Tabulata) from the Gionyama Formation, Miyazaki Prefecture. Bulletin of the National Science Museum, Tokyo, Series C 25, 111-120.

Niko, S. \& Adachi, T. 2000. Silurian multisoleniids (Coelenterata: Tabulata) from the Gion-yama Formation, Miyazaki Prefecture. Bulletin of the National Science Museum, Tokyo, Series C 26, 107-119.

NiKo, S. \& ADACHI, T. 2002. Silurian Alveolitina (Coelenterata: Tabulata) from the Gionyama Formation, Miyazaki Prefecture. Bulletin of the National Science Museum, Tokyo, Series C 28, 9-24.

NiKo, S. \& ADACHI, T. 2004. Additional material of Silurian tabulate corals from the Gionyama Formation, Miyazaki Prefecture. Bulletin of the National Science Museum, Tokyo, Series C 30, 47-54.

Nikolaeva, T.V. 1960. Podclass Tetracoralla (Rugosa), 220-254. In Markovskiy, B.P. (ed.) Novye vidy drevnikh rasteniy $i$ bespozvonochnykh SSSR. Gosgeoltekhizdat, Moscow. 
PedDER, A.E.H. 1976. First records of five rugose coral genera from Upper Silurian rocks of the Canadian Arctic Islands. Geological Survey of Canada paper 76-1B, 287-293.

Pickett, J.W. 1982. The Silurian System in New South Wales. Geological Survey of New South Wales, Bulletin 29, 1-164.

Pickett, J.W., Burrow, C.J., Holloway, D.J., Munson, T.J., Percival, I.G., Rickards, R.B., Sherwin, L., Simpson, A.J., Strusz, D.L., Turner, S. \& Wright, A.J. 2000. Silurian palaeobiogeography of Australia. Memoir of the Association of Australasian Palaeontologists 23, 127-165.

Rong, J.Y. \& CHEN, X. 2003. Silurian biostratigraphy of China, 173-236. In Zhang, W.T., Chen, P. \& Palmer, A.R. (eds) Biostratigraphy of China. Science Press, Beijing.

Saito, M. \& KanBE, N. 1954. Geology of the Sangasho-Kuraoka District, Miyazaki Prefecture: new occurrence of the Gotlandian, Permian and Cretaceous sediments. Bulletin of the Geological Survey of Japan 5(3), 1-7. [in Japanese]

SCRUTTON, C.T. \& Deng, Z.Q. 2002. Rugose and tabulate corals, 102-124. In Holland, C.H. \& Bassett, M.G. (eds) Telychian rocks of the British Isles and China (Silurian, Llandovery Series), an experiment to test precision in stratigraphy. National Museum of Wales, Geological Series 21.

Strusz, D.L. \& Munson, T.J. 1997. Coral assemblages in the Silurian of Eastern Australia: A rugosan perspective. Boletin de la Real Sociedad Española de historia Natural, Sección Geológica 92 (1-4), 311-323.

Sugryama, T. 1939. Geological and geographical distribution of the stromatoporoids from Japan, with notes on some interesting forms. Jubilee Publication in the Commemoration of Prof. H. Yabe's $60^{\text {th }}$ birthday 1, 427-456.

SugiYama, T. 1940. Stratigraphical and palaeontological studies of the Gotlandian deposits of the Kitakami Mountainland. The Science Reports of the Tohoku Imperial University, Series 2, 21(2), 81-146.

Sultanbekova, Z.S. 1986. Rugosa and biostratigraphy of Late Ordovician and Lower Silurian. 122 pp. Nauk' Kazakhstan SSSR, Alma-Ata. [in Russian]

Sytova, V.A. 1966. Rugozy borovushkinskoy svity (vepkhny silur) Rudigo Altaya. Voprosy paleontologii 5, 93-100. [in Russian]

TANG, L. 2006. On Silurian Shensiphyllum Ge et Yü, 1974. Acta Palaeontlogica Sinica 45(3), 374-383. [in Chinese with English summary]

TAZAWA, J. 2004. The strike-slip model: a synthesis on the origin and tectonic evolution of the Japanese Islands. Journal of the Geological Society of Japan 110(9), 503-517. [in Japanese with English abstract]

UmedA, M. 1996. Correlation of the Middle Paleozoic of the Kurosegawa Belt with the Hida Gaien Belt, Southern
Kitakami Belt based on Radiolaria. Chikyu Monthly 18, 718-723. [in Japanese]

UMEDA, M. 1997. A re-examination of the Siluro-Devonian Gionyama Group in the Kurosegawa Terrane, Southwest Japan. Abstracts, the $104^{\text {th }}$ Annual Meeting of the Geological Society of Japan, 380. [in Japanese]

Umeda, M. 1998. The Siluro-Devonian Yokokurayama Group in the Yokokurayama area, Kochi, Southwest Japan. Journal of the Geological Society of Japan 104(6), 365-376. [in Japanese with English abstract]

UmedA, M., Shibata, K. \& IgI, S. 1986. K-Ar ages of hornblende from the granodiorite in the Kuraoka igneous rocks around Mt. Gion-yama in the Kurosegawa structural belt, central Kyushu. Journal of the Geological Society of Japan 92(2), 155-158. [in Japanese]

Wakamatsu, H., Sugiyama, K. \& Furutani, H. 1990. Silurian and Devonian radiolarians from the Kurosegawa Tectonic zone, Southwest, Japan. Journal of Earth Sciences, Nagoya University 37, 157-192.

Wang, B.Y., Zhang, Z.X., Rong, J.Y., WANG, C.Y. \& CAI, T.C. 2001. Silurian and Early Devonian stratigraphy and faunas in Southern Tianshan, Xinjiang. 130 pp. China University of Science and Technology Press, Hefei. [in Chinese]

WANG, C.S., WANG, X.F. \& ChEN, X.H. 2005. Silurian, 155-193. In Centre for Stratigraphy and Palaeontology, China Geological Survey (ed.) Stratigraphic division and correlation of each geological period in China. Geological Publishing House, Beijing. [in Chinese]

Wright, A.J. \& BAUER, J.A. 1995. New Silurian corals from New South Wales. Memoir of the Association of Australasian Palaeontologists 18, 97-104.

Wu, W.S., Liao, W.H. \& Zhao, J.M. 1982. Palaeozoic rugose corals from Xizhang. The series of the scientific expedition to the QinghaiXizang Plateau, Palaeontology of Xizang 4, 107-151. [in Chinese with English abstract]

YounG, G.A. \& EliAs, R.J. 1995. Latest Ordovician to earliest Silurian colonial corals of the east-central United States. Bulletins of American Paleontology 108, 1-148.

Yü, C.M. 1956. Some Silurian corals from the Chiuchuan Basin western Kansu. Acta Palaeontologica Sinica 4(4), 599-620.

YÜ, C.M. 1962. Middle Silurian corals of North Qilianshan. Geology of Qilianshan 4(3), 13-110. [in Chinese]

Zheltonogova, V.A. 1965. Znachenie rugoz dlya stratigrafii silura gornogo Altaya i Salaira, 33-44. In Sokolov, B.S. \& IvanovskiY, A.B. (eds) Rugozy Paleozoya SSSR. Trudy 1. Vsesoyuznogo simpoziuma po izuchenie iskopaemykh korallov SSSR, vypusk. 3. Institut Geologii i Geofiziki, Akademiya Nauk. SSSR, Sibirskoe Otdelenie, Izdatel'stvo Nauka, Moscow. [in Russian] 